IZA DP No. 8225

The Impact of Parents Migration on the Well-being of Children Left Behind: Initial Evidence from Romania

Alina Botezat

Friedhelm Pfeiffer

May 2014 


\title{
The Impact of Parents Migration on the Well-being of Children Left Behind: Initial Evidence from Romania
}

\author{
Alina Botezat \\ 'Gh.Zane' Institute for Economic and Social Research, Romanian Academy \\ Friedhelm Pfeiffer \\ Centre for European Economic Research (ZEW), \\ University of Mannheim and IZA
}

\author{
Discussion Paper No. 8225 \\ May 2014
}

IZA

P.O. Box 7240

53072 Bonn

Germany

Phone: +49-228-3894-0

Fax: +49-228-3894-180

E-mail: iza@iza.org

\begin{abstract}
Any opinions expressed here are those of the author(s) and not those of IZA. Research published in this series may include views on policy, but the institute itself takes no institutional policy positions. The IZA research network is committed to the IZA Guiding Principles of Research Integrity.

The Institute for the Study of Labor (IZA) in Bonn is a local and virtual international research center and a place of communication between science, politics and business. IZA is an independent nonprofit organization supported by Deutsche Post Foundation. The center is associated with the University of Bonn and offers a stimulating research environment through its international network, workshops and conferences, data service, project support, research visits and doctoral program. IZA engages in (i) original and internationally competitive research in all fields of labor economics, (ii) development of policy concepts, and (iii) dissemination of research results and concepts to the interested public.
\end{abstract}

IZA Discussion Papers often represent preliminary work and are circulated to encourage discussion. Citation of such a paper should account for its provisional character. A revised version may be available directly from the author. 


\title{
ABSTRACT \\ The Impact of Parents Migration on the Well-being of Children Left Behind: Initial Evidence from Romania*
}

\begin{abstract}
Many children grow up with parents working abroad. Economists are interested in the achievement and well-being of these "home alone" children to better understand the positive and negative aspects of migration in the sending countries. This paper examines the causal effects of parents' migration on their children left home in Romania, a country where increasingly more children are left behind in recent years. Using samples from a unique representative survey carried out in 2007 instrumental variable and bivariate probit estimates have been performed. Our initial evidence demonstrates that in Romania home alone children receive higher school grades, partly because they increase their time allocation for studying. However, they are more likely to be depressed and more often suffer from health problems especially in rural areas.
\end{abstract}

JEL Classification: I12, I21, J13

Keywords: parent migration, home alone children, well-being, Romania

Corresponding author:

Alina Botezat

Romanian Academy

'Gh.Zane' Institute for Economic and Social Research

2 Teodor Codrescu Street

700481, Iaşi

Romania

E-mail: botezat.alina@yahoo.com

\footnotetext{
* Part of this study has been performed while Alina Botezat was a visiting researcher at the Centre for European Economic Research (ZEW) in Mannheim. Alina Botezat acknowledges support by a grant of the Romanian Ministry of Education, CNCS - UEFISCDI, project number PN-II-RU-PD-2012-3-0541. Both authors gratefully acknowledge support from the College for Interdisciplinary Education Research, a joint initiative of the German Ministry of Education and Research, the Jacobs Foundation and the Leibniz Association. This paper benefited from extremely helpful comments by Eckhard Klieme, Jan Marcus, Jens Mohrenweiser, Frauke Peter, Winfried Pohlmeier, Beatrice Rammstedt and Heike Solga. The views expressed in this article are those of the author and do not necessarily reflect the views of the College for Interdisciplinary Education Research or the Romanian Ministry of Education. All opinions and mistakes are our own.
} 


\section{Introduction}

Migration of parents abroad for working purposes may be an important way of generating income and reducing unemployment in the sending countries. Migration may have also positive and/or negative consequences for children left at home. On the one hand parents often get better paid jobs abroad, providing their children with more financial and educational resources and fostering social and school achievement. On the other hand, however, missing the main adult caregiver may be harmful for children's well-being.

Economists are becoming increasingly interested in the achievement and well-being of the "home alone" children to better understand the overall consequences of migration. While some papers find negative impacts when missing the main adult caregiver (Gibson et al., 2011, Giannelli and Mangiavacchi, 2010, McKenzie and Rapoport, 2011, among others), others find positive effects of parental migration, especially for school outcomes (Gassmann et al., 2013; Macours and Vakis, 2010; Yang, 2008, among others) 1 . The evidence seems to be far from being conclusive. Findings depend on the socio-emotional family environment, the country under investigation as well as the data available. Nevertheless, the literature demonstrates that serious negative consequences cannot be ruled out.

Although migration of adults to work abroad has been a common feature in East-European societies ${ }^{2}$, causal analysis on children's well-being for these countries is specifically scarce. The limited evidence is primarily due to a lack of valid data that can be used by researchers to assess the magnitude of the phenomenon as well as its effects on children left home. To the best of our knowledge this paper is the first to examine the causal effects of parents' migration on their children left home in Romania. To explore causality, an instrumental variables approach is used based on a unique representative survey carried out in 2007, containing a rich set of background and outcome variables. Following previous research (Woodruff and Zenteno, 2007; McKenzie and Rapoport, 2011; Hildebrandt and McKenzie, 2005), the community-level migration rates in 2001/2002 is used as an instrument for current migration. This instrument reflects the strength of migration networks in a region that may facilitate also the process of

\footnotetext{
${ }^{1}$ So far, evidence mainly stems from American and Asian countries; see Antman (2013) for a recent survey on the literature. Studies have been performed for Mexico (Alcaraz et al., 2012, McKenzie and Rapoport, 2011; Hildebrandt and McKenzie, 2005) and other American countries (Cox-Edwards and Ureta, 2003 Acosta, 2011) or Antón (2010). Other studies look at the impact of migration on family members left behind in China (Meyerhoefer and Chen, 2011, $\mathrm{Mu}$ and van de Walle, 2011) or the Philippines (Cortes, 2013, Yang, 2008). A few studies from East Europe are mentioned in section 2.

${ }^{2}$ After the fall of communism, increasingly more individuals from Eastern Europe have chosen to migrate abroad to find a better paid job. Over time, networks between migrants and their peers from home have been developed, which has intensified migration, including families with children. Compared to other world regions, a special feature of these countries is that international migration was something new for these societies. In the last 40 years before 1989, migration abroad was very rare, and if, was in most cases permanent. Internal migration was of course common, especially from rural to urban areas.
} 
current migration due to lower migration costs and lower risks.

The identification assumes that the share of migrants in 2001/2002 does not directly affect children's achievement and well-being 5-6 years later. We perform IV models and in addition assess average treatment effects computed from bivariate probit models for binary outcomes. We find, in accordance with the literature, initial evidence for a significant positive effect of parents' migration on children's school performance as reflected in higher school grades, partly because children left alone increase their time allocation for studying and homework. However, parents' migration seems to cause more seriously health problems. Our estimates demonstrate that children whose parents are abroad more often suffer from mental or physical sickness, confirming Giannelli and Mangiavacchi (2010) and McKenzie and Rapoport (2011), among others. In Romania, the effect seems to be larger for the children from rural areas.

The rest of the paper is structured as follows. Section two discusses the patterns of migration in Eastern Europe and presents the relevant literature. After describing the data in section three, the fourth section focuses on the identification strategy and analyzes possible threats to its validity. Section 5 discusses the estimated results and section six concludes.

\section{Patterns of migration and their families left home in Eastern Europe}

In the past decade, increasingly more parents from countries from Eastern Europe migrate abroad for employment, while their children remain at home. Especially for Romania, the media describe the situation as "a national tragedy" (Bilefsky, 2009, February 14). The first official data that monitors the phenomenon dates back to 2006 in Romania, when almost 60,000 children were registered as having at least one parent working abroad? The largest magnitude was recorded in 2008, when the number of children left behind was higher than 92,000, representing two percent of the child population (from a total of 4,400,000 children aged 0-184).

According to other studies, the official numbers seriously underestimate the phenomenon. Only few parents seem to inform the authorities that they intend to migrate to work abroad, leaving their children at home. According to Toth et al. (2008) almost 350,000 children lived in migrant families and nearly 400,000 children had at some point one or both parents working abroad. Toth et al. (2007) suggests that 170000 junior high school students (almost 20 percent of students enrolled in high school) had parents working outside Romania.

In other Eastern countries similar developments seem to take place. For example, in the Republic of Moldova transnational households are becoming increasingly common. Around 17 percent of Moldavian children live in households with at least one parent working abroad (Sandu, 2011). A recent study by Gassmann et al. (2013) suggests that children's well-being is not adversely

\footnotetext{
${ }^{3}$ Reported by the Romanian Authority for Child Protection, see http://www.copii.ro/alte_categorii.html.

${ }^{4}$ Source: The National Institute of Statistics, Romania.
} 
affected by parental migration in Moldova. Living in a migrant family increased the probability for young adults to attend a university (Görlich et al., 2010).

Albania has also experienced a high magnitude of migration. According to Giannelli and Mangiavacchi (2010) around 22 percent of children live in migrant households. Compared to Romania, where both women and men are equally represented in the migration process, and to Moldova, where the percentage of migrated mothers is higher than those of migrated fathers, children in Albania are mainly left home by their fathers. Father's migration increases the probability of dropping-out at school for their children the most affected being the girls and those living in rural areas. In Bulgaria the problem of parents' migration and their children left behind is well recognized (Guentcheva, 2010), but there are no individual data available for research.

\section{Data}

The paper uses samples from a representative survey carried out in 2007 by the Romanian branch of Gallup International within a project financed by the Soros Foundation. The original data set, which is publicly available $5^{5}$ gathers detailed information about family background, and a wealth of outcomes variables on school achievement and mental and physical well-being of children. A total of 2,037 students from the 5th?8th grades were surveyed, 437 (or 21 percent) of them having at least one parent working abroad.

Our sample is restricted to children, whose parents have worked abroad for at least 12 months. We do so in order to focus on the medium and long-run impact of parents' absence on different children outcomes. According to the literature, children may have worse outcomes regarding school achievement (McLanahan and Sandefur, 1994), health (Page and Stevens, 2004) and overall well-being (Fomby and Cherlin, 2007) when they live in single-parent households.

The reasons underlying the absence of a family member (divorce, migration, and decease) are perceived as different experiences by the other family members. Therefore children' outcomes may also differ. For example Creighton et al. (2009) show that the long-term migration of at least one parent increases the chances of secondary school-aged children to be enrolled in school. On the other hand, in the case when a child's father is dead, the impact on school enrolment is negative. Nobles (2011) shows that the father's absence in the household following divorce has a negative impact on children' school outcomes, while the migration of the father for work purposes has a positive impact on their children.

Therefore, we restrict our sample to those children living in intact families, to isolate the effect of parents' migration from the effects of growing up in divorced families or in households with

\footnotetext{
${ }^{5}$ http://www.soros.ro/?q=node/1303.
} 
one deceased parent. We end up with a sample of 1,433 observations, 291 (or 20 percent) of them having at least one parent working abroad, see the summary statistics in Table A1 and A2 in the Appendix.

\section{Empirical strategy}

\subsection{Estimation technique and variables}

This section explains the econometric framework used to estimate the effects of parents' migration on school performance, health and psychological well-being of their children.

The basic regression model can be expressed as follows:

$$
\text { Outcome }_{i}=\alpha+\beta \text { Migrant }_{i}+\gamma^{\prime} X_{i}+\epsilon_{i}
$$

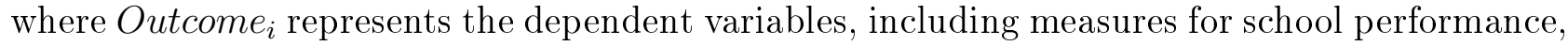
for child's health and mental well-being. Migrant $t_{i}$ is our variable of interest and treated as being endogenous. The variable Migrant $_{i}$ takes the value 1 if a household has at least one parent abroad and 0 otherwise. $X_{i}$ is a vector of control variables, which we introduce below. For school performance we use two measures: students' self-confessed average grade (GPA) for the last semester (fall semester of the school year 2006-2007), GPA from last semester and expected grade point average for the entire 2006-2007 school year, Expected yearly GPA. Since the data were collected in mid-June, when the school year ends in Romania, we hypothesize that the self-reported GPA for the entire school year to coincide with the true one. The grading scheme usually comprises grades from 1 to 10 , with 10 being the highest grade. The minimum passing grade is 5. On average in the sample GPA reaches 8.491. Average GPA is higher in non-migrant compared to migrant households and higher in urban compared to rural regions (see Table A1).

Our further dependent variables are number of hours spent daily for study and homework, study hours and number of hours spent daily for housework, work hours. The specific questions formulated in questionnaire on time use are framed as: "How much time in a day do you spent on learning and doing homework?" respectively, "How much time in a day do you spend helping with household chores?". The answers are then scaled into eight ordered categories: not at all, less than half of hour, 1 hour, 2 hours, 3 hours, 4 hours, 5 hours and more than 5 hours. Children from migrant households spend more time with housework and less time for study compared to children from non-migrant families (see Table A1).

Following Schmeer (2009), we use as outcome for health the variable any illness that was assessed based on the child's report as being ill "pretty often" in the five months prior to the survey. In the same manner we define also the indicator variable being depressed that takes value 1 if the child reports having depressive symptoms as feeling alone, not loved, neglected, afraid, unsure, worried or unhappy. 
As indicators for the psychological well-being of children we also construct two more variables: being bullied, and being involved in conflicts. Following Ammermueller (2012), we define a dummy variable for being bullied at all or not at all. This variable indicates whether the child reports as being victim of violence, measured by being insulted or being scared or hurt or being laughed at in the last five months. We also assess in a similar way the impact of parents' absence on the probability of being involved in conflicts (with the police, or with the neighbors or with other kids) in the last months. As shown in Table A1, children in migrant compared to nonmigrant families are bullied, depressed, or report any illness more often, especially in rural area.

$X_{i}$ represents a vector of covariates. We include individual characteristics such as age, sex and parental education. In order to control for potential initial differences in children's outcomes in the absence of migration, we need also to control for pre-migration family income or wealth that are likely to affect both the migration decision and children education and well-being. Unfortunately, our data contain only post-treatment information regarding the household wealth that is more likely to reflect investments after migration due to potential budget constrains alleviation. Similar to other studies (McKenzie and Rapoport, 2011) we try to proxy for household wealth and socio-economic status using parents' education, i.e whether the mother and the father completed their primary, secondary or tertiary education. In our study, the parents' education is significantly correlated with the number of books at home, which reflect the socioeconomic status of the family, as well as with certain durable assets such as a car or a computer.

In the sample, children are on average 13 years old. The parents of the children from migrant household are, on average, less educated compared to the parents of children from non-migrant households (see Table A2). Other control variables include a dummy variable for urban communities as well as regional dummies. We also consider an index for each counties development, computed for 1998 by Sandu et al. (2000), denoted Devjud98.

Devjud98 has been formed using factorial analysis from 11 indicators regarding human capital, employment, fertility rates and economic capital of households. All respondents living in the same county were assigned the same index value Devjud98. There are 42 counties in Romania, including Bucharest. Spearman rank correlation coefficient test (not shown here) indicates a small but a significant negative correlation between this index of county development and the 2001/2002 share of migrants. As Table A2 shows migration is higher in Moldova and the West as well as in less developed regions.

\subsection{Identification}

We are interested in the estimation of parameter $\beta$ from equation (1). Two of our outcomes (GPA for the last semester and the expected GPA for the entire school year) are continuous. The variables describing the health and the psychological well-being are of binary nature, while ordered variables measure time allocation. Using OLS/Probit to estimate this model, we pre- 
sume that migrant and non-migrant families are similar in both observable and unobservable characteristics. But, in the case of migration, the potential endogeneity of migration may lead to biased estimates. Migrant and non-migrant families are likely to differ in unobservable factors that may also affect the children outcomes.

To control for the potential endogeneity of migration, instrumental variable estimation is applied. We define our instrumental variable, the proportion of migrants from the population in a Romanian community in 2001/2002 (from a total of 174 communities), using data from two sources. The data for villages come from a community census carried out in December 2001 on temporary migration 6 . The respective values for cities and towns are based on the Romanian population and housing census from March 2002 (see Sandu, 2007)7. Past migration history has been used in the literature by Hildebrandt and McKenzie (2005); Lokshin et al. (2010); McKenzie and Rapoport (2011) and Meyerhoefer and Chen (2011), among others. It reflects the strength of migration networks that may facilitate the process of migration due to lower migration costs and lower risks.

Thus, the variable Migrant $_{i}$ is estimated using the following model:

$$
\text { Migrant }_{i}=\theta+\delta Z_{i}+\phi^{\prime} X_{i}+v_{i}
$$

where $Z_{i}$ is the instrumental variable excluded from equation (1), and $X_{i}$ is the vector of covariates used in the previous equation. Since the instrument only varies at the community level, our standard errors are clustered at the community level.

We use simultaneous estimation models to estimate the equations (1) and (2) in a single procedure. In estimation the model when the outcomes variables are continuous, we use the ordinary two-stage least squares (2SLS) estimator. For binary outcomes we employ both IV - and bivariate probit models. As Imbens and Angrist (1994) have shown, when both treatment and outcomes variables are dichotomous, with 2SLS we can only compute Local Average Causal Effects (LATE). In this case, the estimates provide information about the impact of parents' migration on outcome only for those families whose decision to migrate was influence by the share of migrants in the respective community.

In addition, we apply also bivariate probit models that can be used to identify population average causal effects (ATE). The bivariate probit estimator may outperform those from IV analysis, especially when the sample size is small (as is in the case here, see Chiburis et al., 2012). A critical assumption for obtaining consistent estimates within bivariate probit models refers to the jointly bivariate normal distribution of the error terms from the two stages. To test the null hypothesis of bivariate normality we use a goodness-of-fit score test developed by

\footnotetext{
${ }^{6}$ Available at https://sites.google.com/site/dumitrusandu/bazededate. The methodology for collecting the data is described by Sandu (2000).

${ }^{7}$ Thanks to Dumitru Sandu for supplying these migration rates.
} 
Murphy (2007)8

Our identifying assumption is that the share of migrants in 2001/2002 does not directly affect the school performance as well as children well-being 5-6 years later. What are possible threats to its validity? First, it is likely that household's decision to migrate in 2007 does not differ from their decision to migrate 5 years ago. To control for further economic and social factors on the county level that might have an effect on migration, Devjud98 is included in the regression.

A second potential threat is that certain regions (due to short distances or economic conditions) send systematically more people abroad. In order to capture these unobservable region-level factors that may affect both the migration decision as well as children outcomes we include in our regressions also region dummies.

As pointed out by McKenzie and Rapoport (2011), another threat to the validity of the instrument is that the share of migrants in a community also affects prior migration, which in turn may have a direct effect on children outcomes. So we have to make sure that the instrument has no effect on the outcomes of those who come from households unaffected by current migration. To check this, we look at the outcomes of children from nonmigrant households (untreated group) with former migration episodes. We transform our instrument from a continuos measure to a binary one, as in McKenzie and Rapoport (2011).

We define two categories of counties: those with high-migration rates, with values above the median migration rate (1.15), and those with low-migration rates (below the median). For children in nonmigrant households with former migration episodes in the family, we regress our outcomes variables on the new binary measure of our instrument (including covariates). We note that in almost all cases the effect of the share of migrants in a community is statistically insignificant (results are not documented in the paper; they are available upon request). Only for the outcome yearly expected GPA the effect is small and statistically significant.

Next, we verify the relevance of our excluded instrumental variable. Table A3 and A4 in the Appendix show the results from the first stage regression from equation (2). Note that the first stage regression differs slightly due to different number of observations for each outcome variable. The F-statistics on excluded instrument exceeds in almost all cases the Staiger and Stock (1997) rule-of-thumb criteria of 10 for the instrument to be declared weak. Only in the case of rural sample for the outcomes being involved in conflicts and GPAs the F-statistics are slightly smaller than 10 . In all linear probability models from the first stage regressions our instrument is highly significant. The share of migrants has a significantly positive impact on the probability that 5-6 years later at least one parent from a family is working abroad.

\footnotetext{
${ }^{8}$ The Stata command "SCOREGOF" developed by Chiburis (2012) is used.
} 
We also performed regressions without controlling for the county's development (not shown here, but available upon request). The coefficients of our instrument remain unchanged in magnitude and highly significant. The values of the F-statistic on the excluded instrument are similar to the previous case, and the 2SLS estimates of living in a migrant household on children's outcomes are all very similar. Therefore one may reasonably rule out the possibility of the violation of the IV exclusion restriction.

\section{Results and discussion}

\subsection{The impact of migration on school achievement and children's time use}

Table 1 shows the effects of living in migrant families on our two measures of school performance. We present the OLS and 2SLS estimates for each outcome. Without controlling for endogeneity we find significant negative effect of having parents working abroad on school achievement only for children from urban area. However, the IV estimates reveal significant positive effects, both in rural and urban regions. Children from migrant families have, on average, GPAs from last semester higher by 1-3 grade points than the other children.

Table 1: Effects of having parents working abroad on school achievement

\begin{tabular}{|c|c|c|c|c|}
\hline & \multicolumn{2}{|c|}{$\begin{array}{l}\text { GPA from } \\
\text { last semester }\end{array}$} & \multicolumn{2}{|c|}{$\begin{array}{l}\text { Expected yearly } \\
\text { GPA }\end{array}$} \\
\hline & OLS & $2 \mathrm{SLS}$ & OLS & $2 \mathrm{SLS}$ \\
\hline \multirow{2}{*}{ Whole sample } & -0.092 & $1.981^{* * *}$ & -0.104 & $1.363^{* *}$ \\
\hline & $(0.077)$ & $(0.617)$ & $(0.078)$ & $(0.571)$ \\
\hline Observations & 1,112 & 1,112 & 1,097 & 1,097 \\
\hline \multirow{2}{*}{ Urban } & $-0.187^{*}$ & $1.367^{* *}$ & $-0.195^{* *}$ & $1.257^{*}$ \\
\hline & $(0.099)$ & & $(0.096)$ & $(0.742)$ \\
\hline Observations & 554 & 554 & 547 & 547 \\
\hline \multirow{2}{*}{ Rural } & 0.005 & $3.028^{* *}$ & -0.011 & $1.442^{*}$ \\
\hline & $(0.116)$ & $(1.326)$ & $(0.125)$ & $(0.877)$ \\
\hline Observations & 558 & 558 & 550 & 550 \\
\hline
\end{tabular}

The positive impact of parental migration on academic achievement of children left at home may be surprising. However they are in line with findings from other countries. Macours and Vakis (2010), using data for preschool children, find evidence that mother's migration has a positive effect on their children's cognitive outcomes, the driving force of this effect being the increased family income following migration. Arguillas and Williams (2010) provide evidence that having a migrant mother increases the years of schooling of children left home in the 
Philippines. Yang (2008) also shows that children from migrant households experience better schooling outcomes.

The effects of remittances of migrated parents seem to outweigh the detrimental effects of living in a migrant family, and grades improve. Children may be more motivated to learn, knowing that parents have gone abroad to work in order to provide them additional material and educational resources. Or they hope that at some point, they will follow their parents abroad if they perform better at school. Another explanation could be related to the attitude of teachers of these children. Knowing their family situation, teachers could be more tolerant and kind to children from migrant households, trying in a way to compensate for the negative effects of parental migration by avoiding to additionally "punish" them, by giving them lower marks.

Other studies show that missing the main adult caregiver may be harmful for school achievement, although they measure different outcomes. Giannelli and Mangiavacchi (2010) find evidence for Albania that the absence of the father following migration has a negative impact on school attendance, the effect being higher for girls than for boys. Also, McKenzie and Rapoport (2011) find that living in migrant households lowers the probability for children to finish a high school.

Next, we also analyze how children's daily time allocation between study and housework changes, in response to parents' migration. Table 2 presents the results.

Columns two and three show the OLS and 2SLS estimates. The next columns present the coefficients of ordered probit and IV ordered probit models. In order to generate the two stage ordered probit results, both when we control or not for endogeneity (columns 3 and 4), the models are estimated using the user-written Conditional Mixed Process (CMP) Command in Stata, developed by Roodman (2011).

When we assess the impact of living in migrant families on the number of hours spent daily for homework, significant effects are obtained in the ordered probit models (Columns 3 and 4) and only for the restricted samples. When we control for endogeneity, we see that having parents working abroad increases study hours for children from urban areas. For those from rural communities the effect is negative, but not statistically significant. 
Table 2: Effects of having parents working abroad on children's daily time allocation

\begin{tabular}{|c|c|c|c|c|}
\hline & $(1)$ & $(2)$ & (3) & (4) \\
\hline & OLS & 2SLS & $\begin{array}{c}\text { Ordered } \\
\text { probit }\end{array}$ & $\begin{array}{c}\text { IV- Ordered } \\
\text { probit }\end{array}$ \\
\hline \multicolumn{5}{|c|}{ Dependent variable: study hours } \\
\hline \multirow{2}{*}{ Whole sample } & 0.031 & 0.082 & 0.051 & -0.114 \\
\hline & $(0.107)$ & $(0.763)$ & $(0.075)$ & $(0.460)$ \\
\hline \multirow{2}{*}{ Urban } & -0.131 & 1.021 & -0.070 & $0.732^{* *}$ \\
\hline & $(0.141)$ & $(0.728)$ & $(0.104)$ & $(0.340)$ \\
\hline \multirow{2}{*}{ Rural } & 0.205 & -0.851 & $0.188^{*}$ & -0.461 \\
\hline & $(0.161)$ & $(1.276)$ & $(0.109)$ & $(0.550)$ \\
\hline \multicolumn{5}{|c|}{ Dependent variable: work hours } \\
\hline \multirow{2}{*}{ Whole sample } & -0.059 & -0.127 & -0.072 & 0.081 \\
\hline & $(0.103)$ & $(0.801)$ & $(0.076)$ & $(0.321)$ \\
\hline \multirow{2}{*}{ Urban } & -0.00004 & 0.155 & -0.013 & 0.664 \\
\hline & $(0.127)$ & $(0.57)$ & $(0.107)$ & $(0.648)$ \\
\hline \multirow{2}{*}{ Rural } & -0.116 & -0.408 & -0.136 & -0.366 \\
\hline & $(0.159)$ & $(1.432)$ & $(0.109)$ & $(0.340)$ \\
\hline
\end{tabular}

Standard errors in parentheses are clustered at the community level.

$*, * *, * * *$ indicates significance at the $10 \%, 5 \%$, and $1 \%$ level, respectively.

All regressions include the full set of controls as in Table A2

Having parents abroad seem to have no impact on children's time allocation for housework. Nevertheless, the point estimates are positive for children from urban areas and negative for those from rural areas (column 4). These findings appear to partially stand in contrast with those from Antman (2011), who report that in Mexico children decrease their study hours and spend more time with household work in response to a father's migration to U.S.

\subsection{The impact of migration on mental well-being of children left home}

Table 3 presents results on children's health and mental well-being. Without controlling for possible endogeneity, the estimates from the probit regressions (column two and three) show a significant increase in the probability of being depressed of those children whose parents are working abroad, the marginal effects being larger for children from urban areas.

The next columns present the causal effects of having at least one parent working abroad. The estimates for all children show that parents' migration is linked to more seriously health problems and to a higher probability of suffering from depression. The risk of getting sick more frequently is raised by almost 60 percent, as shown by the 2SLS estimates, the average treatment effect being slightly smaller in magnitude, but statistically significant, in the bivariate probit analysis. The size of the average treatment effect of being depressed is also large in 
Table 3: Effects of having parents working abroad on children's well-being

\begin{tabular}{|c|c|c|c|c|c|c|}
\hline & \multicolumn{2}{|l|}{ Probit } & \multicolumn{2}{|c|}{ 2SLS } & \multicolumn{2}{|c|}{ Bivariate probit } \\
\hline & Avg. Marg. Eff. & Std.dev. & Marg.Eff. & Std.dev. & ATE & Std.dev. \\
\hline & \multicolumn{6}{|c|}{ Whole sample } \\
\hline $\begin{array}{r}\text { being } \\
\text { bullied }\end{array}$ & 0.002 & 0.036 & 0.207 & 0.414 & 0.119 & 0.278 \\
\hline $\begin{array}{l}\text { involved } \\
\text { in conflict }\end{array}$ & 0.024 & 0.035 & 0.133 & 0.257 & 0.134 & 0.194 \\
\hline $\begin{array}{r}\text { being } \\
\text { depressed }\end{array}$ & $0.085^{* * *}$ & 0.024 & 0.458 & 0.344 & $0.404^{*}$ & 0.221 \\
\hline \multirow[t]{2}{*}{$\begin{array}{l}\text { having } \\
\text { any illness }\end{array}$} & 0.025 & 0.031 & 0.572 & 0.353 & $0.412^{* *}$ & 0.168 \\
\hline & \multicolumn{6}{|c|}{ Urban } \\
\hline $\begin{array}{r}\text { being } \\
\text { bullied }\end{array}$ & -0.027 & 0.046 & -0.420 & 0.433 & -0.376 & 0.271 \\
\hline $\begin{array}{l}\text { involved } \\
\text { in conflict }\end{array}$ & 0.028 & 0.046 & 0.013 & 0.213 & -0.006 & 0.150 \\
\hline $\begin{array}{r}\text { being } \\
\text { depressed }\end{array}$ & $0.093^{* * *}$ & 0.033 & 0.021 & 0.310 & 0.028 & 0.328 \\
\hline \multirow[t]{2}{*}{$\begin{array}{l}\text { having } \\
\text { any illness }\end{array}$} & 0.062 & 0.045 & 0.253 & 0.300 & 0.224 & 0.236 \\
\hline & \multicolumn{6}{|c|}{ Rural } \\
\hline $\begin{array}{r}\text { being } \\
\text { bullied }\end{array}$ & 0.026 & 0.055 & 0.772 & 0.617 & 0.393 & 0.306 \\
\hline $\begin{array}{l}\text { involved } \\
\text { in conflict }\end{array}$ & 0.022 & 0.054 & 0.382 & 0.440 & 0.416 & 0.248 \\
\hline $\begin{array}{r}\text { being } \\
\text { depressed }\end{array}$ & $0.066^{*}$ & 0.037 & 0.818 & 0.584 & 0.348 & 0.251 \\
\hline $\begin{array}{r}\text { having } \\
\text { any illness }\end{array}$ & -0.023 & 0.043 & 0.848 & 0.656 & $0.441^{*}$ & 0.247 \\
\hline
\end{tabular}

Standard errors are clustered at the community level. For the ATEs after Bivariate probit standard errors were obtained from 200 bootstrap samplings.

$*, * *, * * *$ indicates significance at the $10 \%, 5 \%$, and $1 \%$ level, respectively.

All regressions include the full set of controls as in Table A2. 
magnitude and statistically significant when using whole sample.

Running regressions separately for the urban and rural samples demonstrates that the children from rural areas are more affected by the parents' migration. The results from the bivariate probit analysis provide evidence that children growing up in migrant households are about 44 percent more likely to get sick, compared to children in non-migrant families. The estimates for the urban sample do not document any statistically significant impact of having at least one parent working abroad on the well-being of left behind children.

Comparison of the probit and IV estimates shows that the effects are larger when we control for the endogeneity of migration, a common feature in most migrational studies (Vargas-Silva, 2012). Formally, this means that the respective effects are underestimated. With respect to substance this suggests that children with parents working abroad have unobserved characteristics that lower their risk of being negatively affected by the absence of their parents.

These findings are in line with the literature showing that parental migration has a negative effect on health and psychological well-being of children left home (Gibson et al., 2011; Dreby, 2007; Mazzucato and Schans, 2011). Living in migrant families, where the main caregiver is abroad for working purposes, has a negative impact on the emotional well-being of children left behind. Most affected are those who must take care self of themselves following the migration of their parents (Lahaie et al., 2009).

Finally, given our findings that, on the one hand, children left home by their migrant parents are more likely to suffer from health problems but, on the other hand, they receive higher grades in school, we examine the link between reporting any illness and school outcomes. More specifically, we look to what extent the educational outcomes of children from migrant households who report health problems differ from the school results of those children left behind who do not report having any illness.

Our results (not presented here, but available upon request) show that there are no statistically significant differences in the means of school performance between the two groups of left behind children defined by their health status. Nonetheless, children who report health problems have, on average, slightly higher grades. This result seems to provide some support for our hypothesis that these children may benefit at school from a tolerant attitude of the teachers.

\section{Conclusions}

This paper is, to the best of our knowledge, the first to examine the causal effects of Romanian parents' migration on their children left home, using data from a unique representative survey carried out in 2007. An instrumental variable approach is used to get around the endogeneity of parental migration. Our identifying assumption is that the share of migrants in $2011 / 2002$ 
does not affect directly the school performance as well as children's well-being 5-6 years later.

The findings hint at a significant positive effect of parents' migration on school performance of children as reflected in higher school grades. Parental migration has an impact on the time allocation of children for study and homework, especially for children from urban areas. These children significantly increase their time on doing study and homework, while no significantly effect was obtained in case of those from rural areas. Therefore the positive effects of migration seem to outweigh the detrimental effects of parental absence with respect to school performance.

However, parents' migration is related to more seriously mental and physical health problems. Our estimates demonstrate that children whose parents are abroad more often get sick or depressed, the effect being larger for the children from rural areas. We see our findings as initial evidence mainly because longitudinal data are still missing. The two types of outcomes under investigation, school achievement and mental and physical well-being may be interrelated in manifold ways with unknown long run consequences. To get a deeper understanding of these complex interactions and on the longer run impacts on children's achievement longitudinal data are needed.

Nevertheless, our initial findings may have some relevance for Romanian policymakers and institutions who are concerned about detrimental effects of parental migration on children left home. Concern is needed since migration may increase even further, given the full integration into the European Union. Our findings suggest that migration seem to have positive as well negative impacts on the children left at home, depending on the outcomes under investigation. It should be the task of families and policy makers to search for effective policies reducing the harmful impacts of migration on children's development and fostering positive impacts. 


\section{References}

Acosta, P. (2011). "School Attendance, Child Labour, and Remittances from International Migration in El Salvador". Journal of Development Studies, 47(6), pp. 913-936.

Alcaraz, C., Chiquiar, D., and Salcedo, A. (2012). "Remittances, schooling, and child labor in Mexico". Journal of Development Economics, 97(1), pp. 156-165.

Ammermueller, A. (2012). "Violence in European schools: A widespread phenomenon that matters for educational production". Labour Economics, 19(6), pp. 908 - 922.

Antman, F. (2013). "The Impact of Migration on Family Left Behind". in: A. Constant, K. F. Zimmermann, International Handbook on the Economics of Migration, Edward Elgar: Northampton, $M A$.

Antman, F. M. (2011). "The intergenerational effects of paternal migration on schooling and work: What can we learn from children's time allocations?". Journal of Development Economics, 96(2), pp. $200-208$.

Antón, J.-I. (2010). "The Impact of Remittances on Nutritional Status of Children in Ecuador". International Migration Review, 44(2), pp. 269-299.

Arguillas, M. J. B. and Williams, L. (2010). "The Impact of Parents' Overseas Employment on Educational Outcomes of Filipino Children". International Migration Review, 44(2), pp. 300-319.

Bilefsky, D. (2009, February 14). "'In Romania, Children Left Behind Suffer the Strains of Migration". New York Times, Retrieved from http://www.nytimes.com/2009/02/15/world/europe/15romania.html.

Chiburis, R. (2012). "SCOREGOF: Stata module to perform Score test of normality for probit and bivariate probit". Statistical Software Components.

Chiburis, R. C., Das, J., and Lokshin, M. (2012). "A practical comparison of the bivariate probit and linear IV estimators". Economics Letters, 117(3), pp. 762-766.

Cortes, P. (2013). "The Feminization of International Migration and its Effects on the Children Left Behind: Evidence from the Philippines". World Development, (0), pp. -.

Cox-Edwards, A. and Ureta, M. (2003). 'International migration, remittances, and schooling: evidence from El Salvador". Journal of Development Economics, $72(2)$, pp. 429 - 461.

Creighton, M., Park, H., and Teruel, G. (2009). "The role of migration and single motherhood in upper secondary education in Mexico". Journal of Marriage and Family, 71(5), pp. $1325-1339$. 
Dreby, J. (2007). "Children and power in Mexican transnational families". Journal of Marriage and Family, 69(4), pp. 1050-1064.

Fomby, P. and Cherlin, A. J. (2007). "Family Instability and Child Well-Being". American Sociological Review, 72(2), pp. 181-204.

Gassmann, F., Siegel, M., Vanore, M., and Waidler, J. "The impact of migration on children left behind in Moldova". Technical report, United Nations University, Maastricht Economic and social Research and training centre on Innovation and Technology, (2013).

Giannelli, G. C. and Mangiavacchi, L. (2010). "Children's Schooling and Parental Migration: Empirical Evidence on the "Left-behind" Generation in Albania". LABOUR, 24, pp. 76-92.

Gibson, J., McKenzie, D., and Stillman, S. (2011). "What happens to diet and child health when migration splits households? Evidence from a migration lottery program". Food Policy, $36(1)$, pp. $7-15$.

Görlich, D., Mahmoud, O. T., and Trebesch, C. (2010). "Explaining labour market inactivity in migrant-sending families: housework, hammock, or higher education?".

Guentcheva, R. (2010). "Long Distance Relationships: Children and Migration in Contemporary Bulgaria". Ethnologia Balkanica, (14), pp. 49-69.

Hildebrandt, N. and McKenzie, D. (2005). "The Effects of Migration on Child Health in Mexico". Economia, 6(1), pp. 257-289.

Imbens, G. and Angrist, J. D. (1994). 'Identification and Estimation of Local Average Treatment Effects". Econometrica, 62(2), pp. 467-75.

Lahaie, C., Hayes, J. A., Piper, T. M., and Heymann, J. (2009). "Work and family divided across borders: The impact of parental migration on Mexican children in transnational families". Community, Work \& Family, 12(3), pp. 299-312.

Lokshin, M., Bontch-Osmolovski, M., and Glinskaya, E. (2010). "Work-Related Migration and Poverty Reduction in Nepal". Review of Development Economics, 14(2), pp. 323-332.

Macours, K. and Vakis, R. (2010). "Seasonal Migration and Early Childhood Development". World Development, 38(6), pp. 857 - 869.

Mazzucato, V. and Schans, D. (2011). "Transnational Families and the Well-Being of Children: Conceptual and Methodological Challenges". Journal of Marriage and Family, 73(4), pp. 704-712.

McKenzie, D. and Rapoport, H. (2011). "Can migration reduce educational attainment? Evidence from Mexico". Journal of Population Economics, 24, pp. 1331-1358. 
McLanahan, S. and Sandefur, G. (1994). Growing up with a single parent: What hurts, what helps. Harvard University Press.

Meyerhoefer, C. and Chen, C. (2011). "The effect of parental labor migration on children's educational progress in rural china". Review of Economics of the Household, 9, pp. 379-396.

Mu, R. and van de Walle, D. (2011). "Left behind to farm? Women's labor re-allocation in rural China". Labour Economics, 18, pp. S83-S97.

Murphy, A. (2007). "Score tests of normality in bivariate probit models". Economics Letters, $95(3)$, pp. $374-379$.

Nobles, J. (2011). "Parenting From Abroad: Migration, Nonresident Father Involvement, and Children's Education in Mexico". Journal of Marriage and Family, 73(4), pp. 729-746.

Page, M. and Stevens, A. (2004). "The economic consequences of absent parents". Journal of Human Resources, 39(1), pp. 80-107.

Roodman, D. (2011). "Fitting fully observed recursive mixed-process models with cmp". Stata Journal, 11(2), pp. 159-206.

Sandu, D. (2007). "Community Selectivity of Temporary Emigration from Romania". Romanian Journal of Population Studies, 1-2, pp. 11-45.

Sandu, D. (2000). "Migraţia transnaţională a românilor din perspectiva unui recensământ comunitar". Sociologie românească, 3-4, pp. 5-52.

Sandu, D., Berevoescu, I., Stănculescu, M., and Tufiş, C. (2000). "The Villages of Romania: Development, Poverty, and Social Capital. Updating Targeting for RSDF". World Bank.

Sandu, V. (2011). "Moldova: the situation of children and elderly left behind by migrants". Policy Review Paper, Maastricht University.

Schmeer, K. (2009). "Father absence due to migration and child illness in rural Mexico". Social Science \& Medicine, 69(8), pp. 1281 - 1286.

Staiger, D. and Stock, J. H. (1997). "Instrumental Variables Regression with Weak Instruments". Econometrica, pages 557-586.

Toth, A., Munteanu, D., and Bleahu, A. (2008). "Analiza la nivel national asupra fenomenului copiilor ramasi acasa prin plecarea parintilor la munca in strainatate".

Toth, G., Toth, A., Voicu, O., and Stefanescu, M. (2007). "Efectele migratiei: Copii ramasi acasa". Soros Foundation Romania, page Bucharest.

Vargas-Silva, C. (2012). Handbook of Research Methods in Migration. Edward Elgar Pub. 
Woodruff, C. and Zenteno, R. (2007). "Migration networks and microenterprises in Mexico". Journal of Development Economics, 82(2), pp. 509 - 528.

Yang, D. (2008). 'International Migration, Remittances and Household Investment: Evidence from Philippine Migrants' Exchange Rate Shocks". The Economic Journal, 118(528), pp. $591-630$. 


\section{Appendix}

Table A1: Summary statistics for outcome variables

\begin{tabular}{|c|c|c|c|c|c|c|c|c|c|c|}
\hline & \multicolumn{2}{|c|}{ All Households } & \multicolumn{4}{|c|}{ Migrant households } & \multicolumn{4}{|c|}{ Nonmigrant households } \\
\hline & & & \multicolumn{2}{|c|}{ urban } & \multicolumn{2}{|c|}{ rural } & \multicolumn{2}{|c|}{ urban } & \multicolumn{2}{|c|}{ rural } \\
\hline & Mean & $\begin{array}{l}\text { Std. } \\
\text { dev. }\end{array}$ & Mean & $\begin{array}{l}\text { Std. } \\
\text { dev. }\end{array}$ & Mean & $\begin{array}{l}\text { Std. } \\
\text { dev. }\end{array}$ & Mean & $\begin{array}{r}\text { Std. } \\
\text { dev. }\end{array}$ & Mean & $\begin{array}{l}\text { Std. } \\
\text { dev. }\end{array}$ \\
\hline & \multicolumn{10}{|c|}{ Outcome variables } \\
\hline $\begin{array}{l}\text { GPA for the } \\
\text { last semester }\end{array}$ & 8.491 & 1.14 & 8.412 & 1.11 & 8.349 & 1.11 & 8.649 & 1.06 & 8.393 & 1.21 \\
\hline $\begin{array}{l}\text { Yearly } \\
\text { expected GPA }\end{array}$ & 8.538 & 1.12 & 8.462 & 1.12 & 8.370 & 1.11 & 8.683 & 1.05 & 8.456 & 1.18 \\
\hline study hours & 2.123 & 1.49 & 1.976 & 1.32 & 2.286 & 1.63 & 2.177 & 1.47 & 2.073 & 1.52 \\
\hline work hours & 1.415 & 1.39 & 1.252 & 1.32 & 1.626 & 1.55 & 1.133 & 1.13 & 1.659 & 1.50 \\
\hline $\begin{array}{l}\text { being } \\
\text { bullied }\end{array}$ & 0.561 & - & 0.556 & - & 0.576 & - & 0.594 & - & 0.527 & - \\
\hline $\begin{array}{l}\text { involved in } \\
\text { conflicts }\end{array}$ & 0.601 & - & 0.637 & - & 0.551 & - & 0.631 & - & 0.575 & - \\
\hline $\begin{array}{l}\text { being } \\
\text { depressed }\end{array}$ & 0.212 & - & 0.272 & - & 0.307 & - & 0.176 & - & 0.208 & - \\
\hline any illness & 0.357 & - & 0.424 & - & 0.336 & - & 0.368 & - & 0.336 & - \\
\hline $\begin{array}{l}\text { Number of } \\
\text { observations }\end{array}$ & & & & & & & & & & \\
\hline
\end{tabular}

${ }^{a}$ Provided for non-dummy variables. 
Table A2: Summary statistics for migration, control and instrumental variables

\begin{tabular}{|c|c|c|c|c|c|c|c|c|c|c|}
\hline & \multicolumn{2}{|c|}{ All Households } & \multicolumn{4}{|c|}{ Migrant households } & \multicolumn{4}{|c|}{ Nonmigrant households } \\
\hline & & & \multicolumn{2}{|c|}{ urban } & \multicolumn{2}{|c|}{ rural } & \multicolumn{2}{|c|}{ urban } & \multicolumn{2}{|c|}{ rural } \\
\hline & Mean & $\begin{array}{l}\text { Std. } \\
\text { dev. }\end{array}$ & Mean & $\begin{array}{l}\text { Std. } \\
\text { dev. }\end{array}$ & Mean & $\begin{array}{l}\text { Std. } \\
\text { dev. }{ }^{a}\end{array}$ & Mean & $\begin{array}{l}\text { Std. } \\
\text { dev. }\end{array}$ & Mean & $\begin{array}{l}\text { Std. } \\
\text { dev. }\end{array}$ \\
\hline \multicolumn{11}{|l|}{$\begin{array}{l}\text { Proportion of households } \\
\text { with at least one parent } \\
\text { abroad }\end{array}$} \\
\hline & \multicolumn{10}{|c|}{ Control variables } \\
\hline Child's age & 13.06 & 1.21 & 13.06 & - & 13.12 & - & 13.07 & - & 13.05 & 1.23 \\
\hline Child is male & 0.52 & - & 0.53 & - & 0.45 & - & 0.55 & - & 0.51 & - \\
\hline \multicolumn{11}{|l|}{ Mother's education } \\
\hline Lower secondary or less & 0.3 & - & 0.21 & - & 0.39 & - & 0.16 & - & 0.43 & - \\
\hline Upper secondary & 0.56 & - & 0.61 & - & 0.59 & - & 0.59 & - & 0.52 & - \\
\hline Tertiary & 0.14 & - & 0.19 & - & 0.02 & - & 0.25 & - & 0.05 & - \\
\hline \multicolumn{11}{|l|}{ Father's education } \\
\hline Lower secondary or less & 0.26 & - & 0.18 & - & 0.4 & - & 0.16 & - & 0.36 & - \\
\hline Upper secondary & 0.61 & - & 0.65 & - & 0.57 & - & 0.63 & - & 0.58 & - \\
\hline Tertiary & 0.13 & - & 0.17 & - & 0.03 & - & 0.21 & - & 0.06 & - \\
\hline \multicolumn{11}{|l|}{ Regional variables } \\
\hline Moldova & 0.29 & - & 0.33 & - & 0.45 & - & 0.22 & - & 0.32 & - \\
\hline West regions & 0.14 & - & 0.17 & - & 0.16 & - & 0.12 & - & 0.15 & - \\
\hline Transylvania & 0.18 & - & 0.17 & - & 0.07 & - & 0.23 & - & 0.15 & - \\
\hline $\begin{array}{l}\text { South regions including } \\
\text { Bucharest }\end{array}$ & 0.39 & - & 0.32 & - & 0.32 & - & 0.43 & - & 0.38 & - \\
\hline Urban & 0.49 & & 1 & - & 0 & - & 1 & - & 0 & - \\
\hline Devjud98 & 18.1 & 118.06 & 21.19 & 127.21 & -27.53 & 90.08 & 48.02 & 126.49 & 0.14 & 105.96 \\
\hline & \multicolumn{10}{|c|}{ Instrument } \\
\hline Share of migrants & 1.94 & 2.41 & 2.63 & 2.29 & 2.59 & 3.47 & 1.87 & 1.82 & 1.66 & 2.56 \\
\hline $\begin{array}{l}\text { Number of } \\
\text { observations }\end{array}$ & \multicolumn{2}{|c|}{1,433} & \multicolumn{4}{|c|}{291} & \multicolumn{4}{|c|}{1,142} \\
\hline
\end{tabular}

${ }^{a}$ Provided for non-dummy variables 


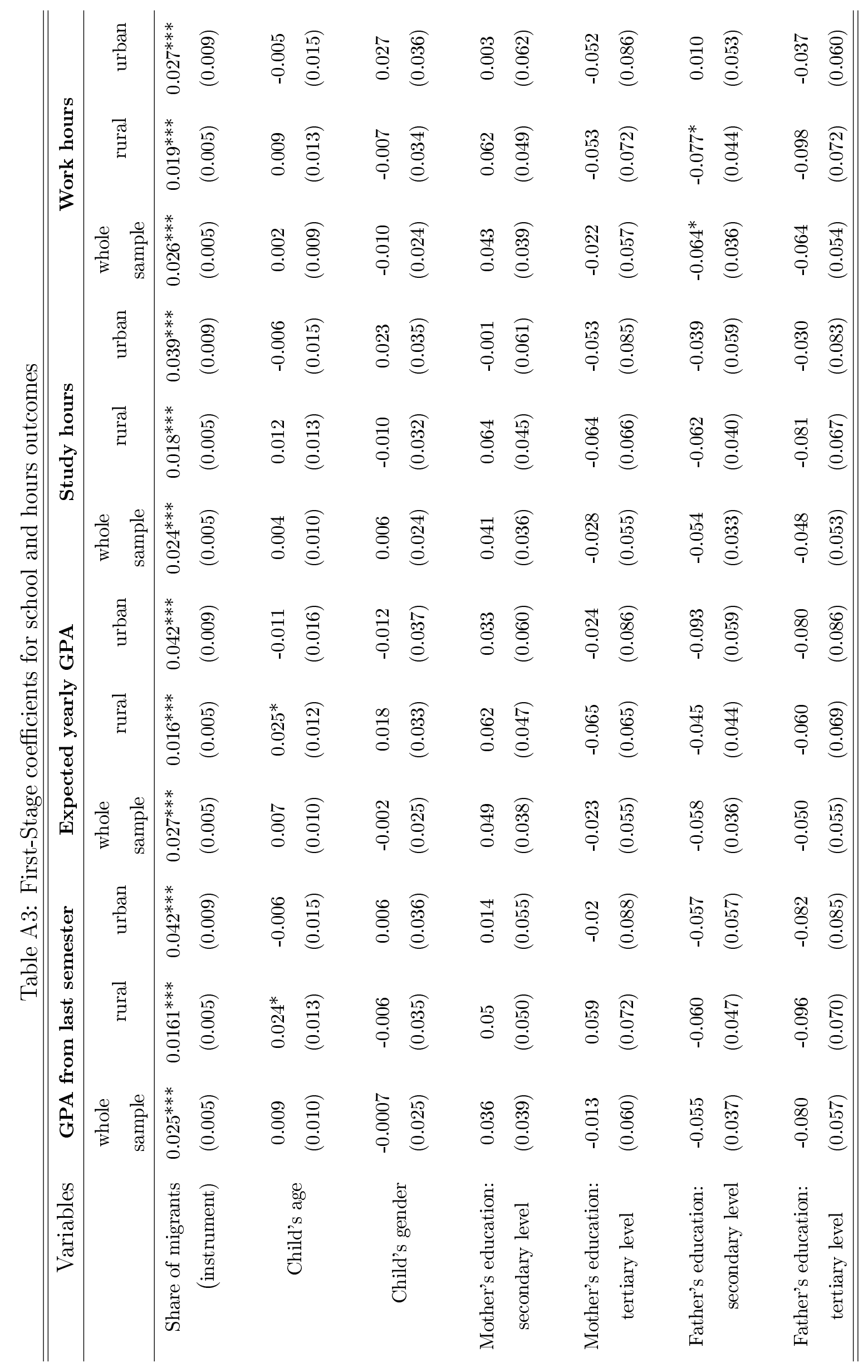




\begin{tabular}{|c|c|c|c|c|c|c|c|c|}
\hline & 营 & 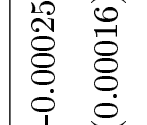 & & 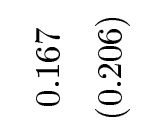 & $\mathscr{D}$ & $\stackrel{0}{9}$ & 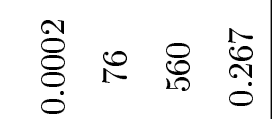 & \\
\hline 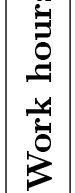 & 㔄 & 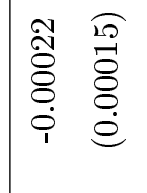 & & 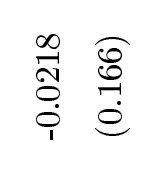 & $\stackrel{\mathscr{D}}{\mathrm{D}}$ & $\begin{array}{l}\infty \\
\stackrel{\infty}{\infty} \\
\stackrel{\rho}{\infty}\end{array}$ & 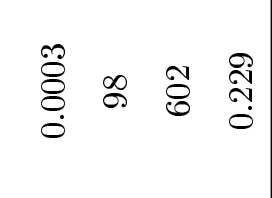 & \\
\hline & 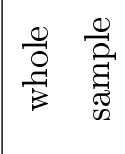 & 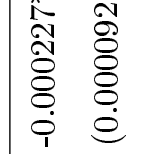 & 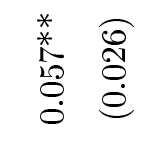 & $\stackrel{8}{\stackrel{8}{\oplus}}$ & 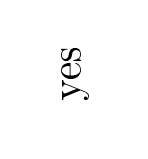 & 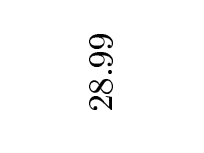 & 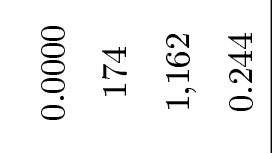 & \\
\hline & 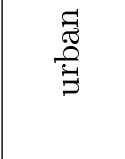 & 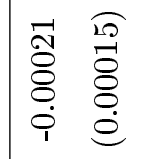 & & 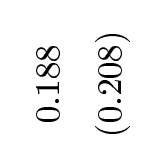 & 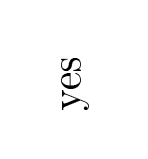 & 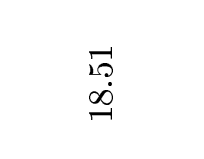 & 总 & \\
\hline 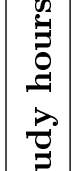 & 㩊 & 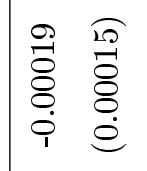 & & 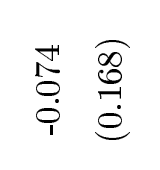 & $\stackrel{\infty}{\infty}$ & ב̃ & 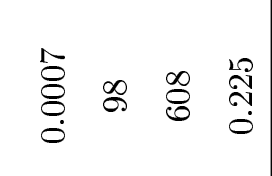 & \\
\hline & 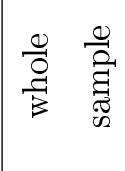 & 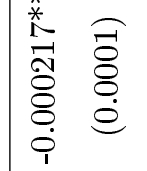 & 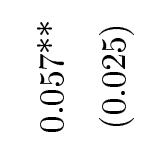 & 兽 & 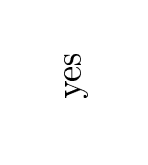 & $\stackrel{2 s}{N}$ & 兽志兽 & \\
\hline 峁 & 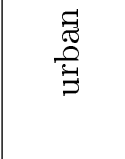 & 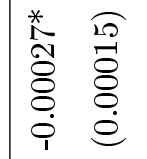 & & 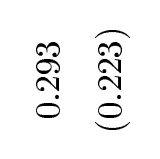 & 品 & 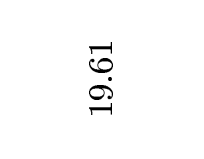 & 壳 & \\
\hline 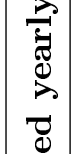 & 票 & 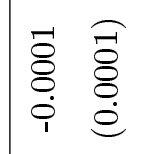 & & 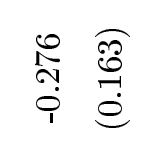 & 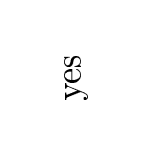 & $\begin{array}{l}\infty \\
\substack{\infty \\
\infty \\
\infty}\end{array}$ & $\begin{array}{l}\mathscr{g} \\
\stackrel{0}{0} \infty\end{array}$ & \\
\hline 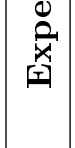 & 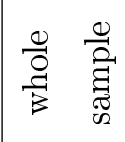 & 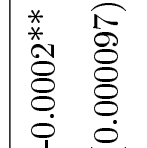 & 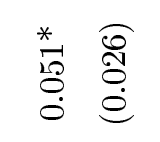 & 兽 & $\mathscr{D}$ & $\vec{\pi}$ & 总 & \\
\hline 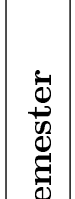 & 宽 & 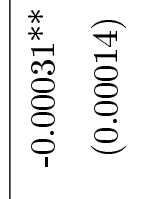 & & 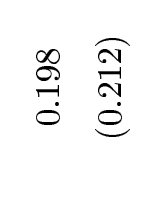 & 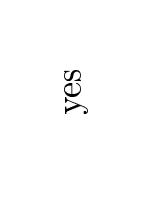 & 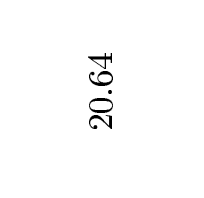 & $\underset{0}{0}$ & \\
\hline 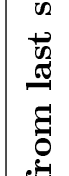 & 要 & 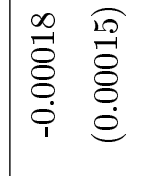 & & 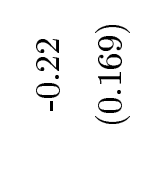 & $\stackrel{\mathscr{D}}{\mathrm{D}}$ & 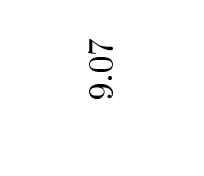 & 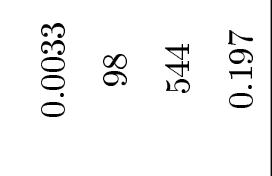 & \\
\hline 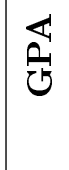 & $\frac{0}{\circ}$ & 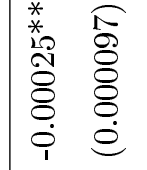 & 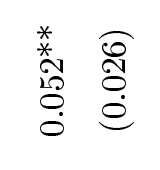 & 量 & $\stackrel{\mathscr{D}}{\mathrm{D}}$ & $\stackrel{g}{g}$ & 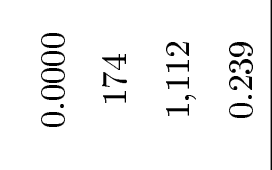 & \\
\hline & & $\begin{array}{l}\infty \\
\stackrel{\infty}{0} \\
\stackrel{0}{0} \\
\stackrel{0}{0}\end{array}$ & 营 & $\begin{array}{l}\text { : } \\
\text { 产 } \\
\text { 总 } \\
0\end{array}$ & 常 & 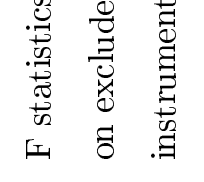 & 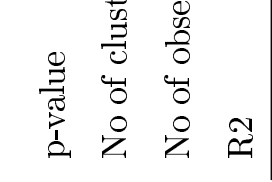 & \\
\hline
\end{tabular}




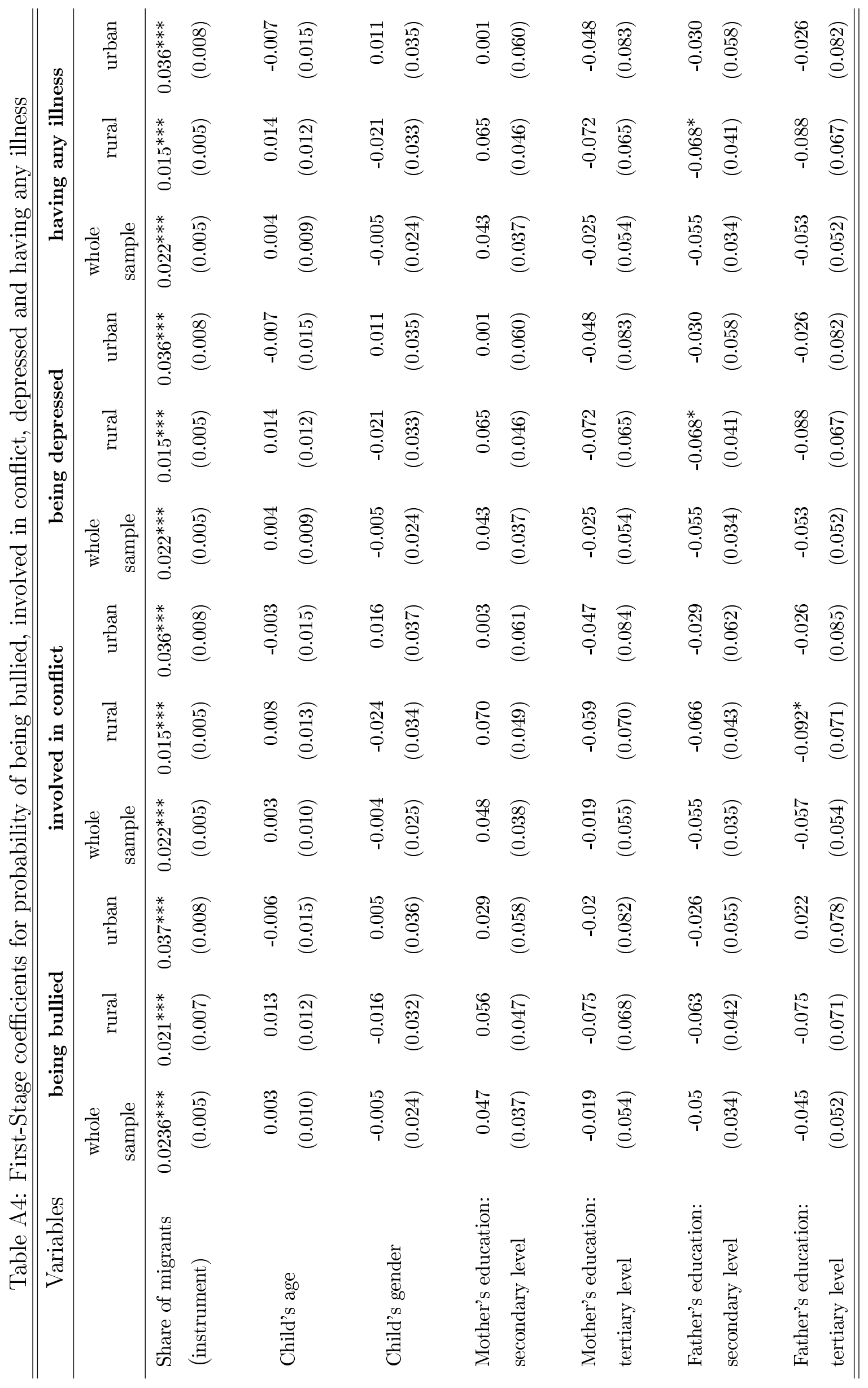




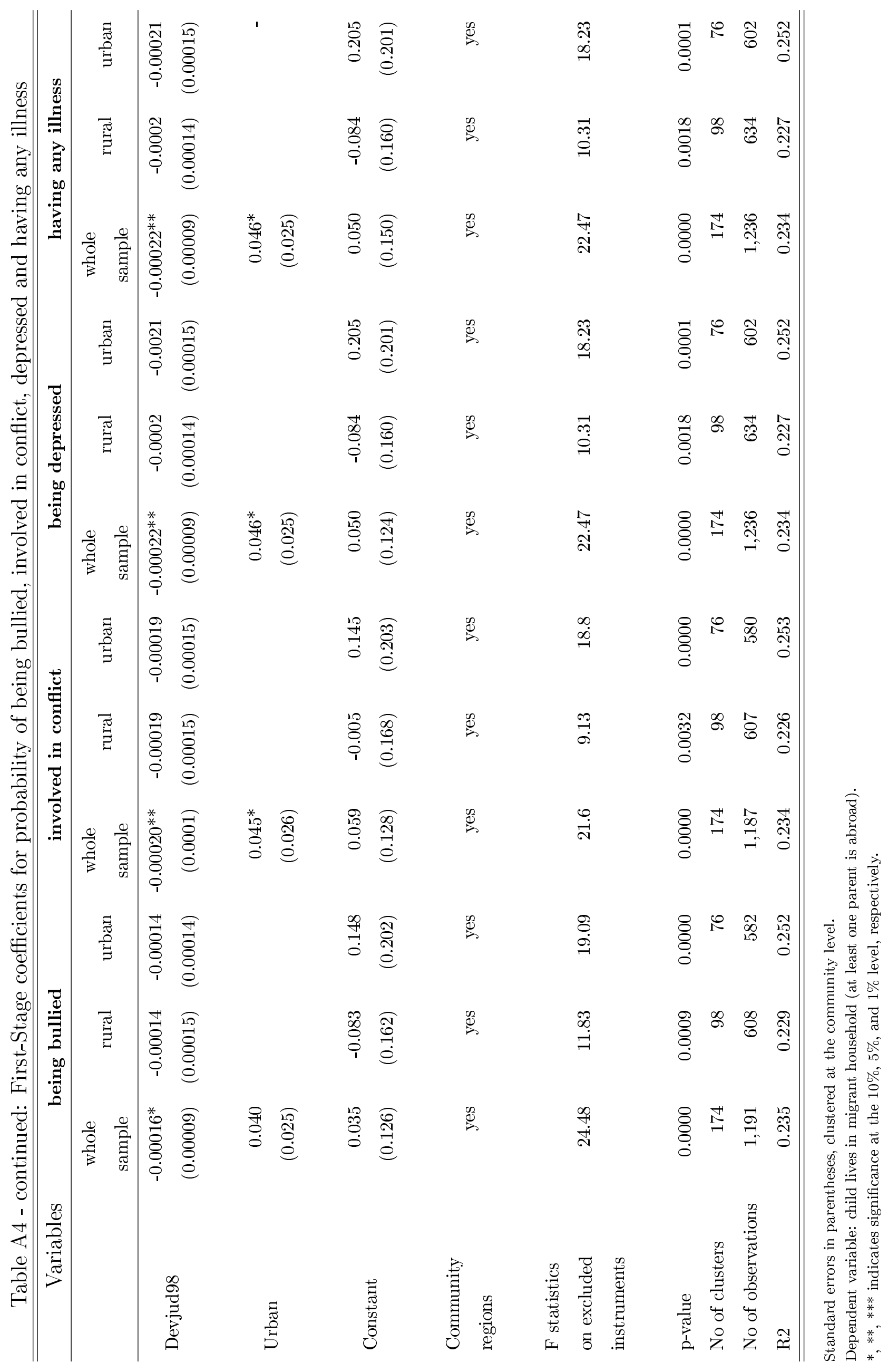

